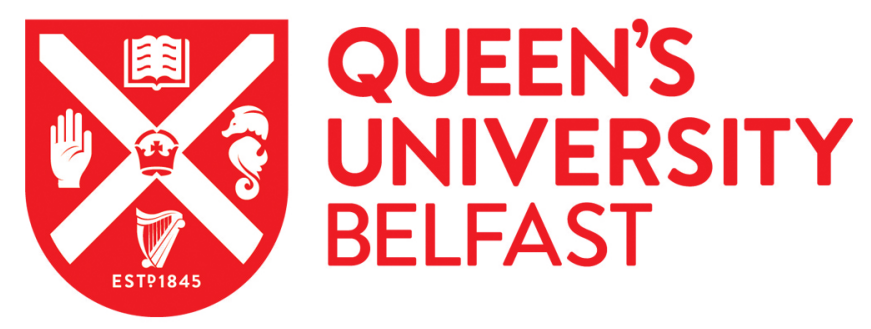

\title{
Community treatment orders and mental health social work: Issues for policy and practice in the UK and Ireland
}

Campbell, J., Davidson, G., McCusker, P., Jobling, H., \& Slater, T. (2019). Community treatment orders and mental health social work: Issues for policy and practice in the UK and Ireland. International Journal of Law and Psychiatry, 64, 230-237. https://doi.org/10.1016/j.ijlp.2019.04.003

Published in:

International Journal of Law and Psychiatry

Document Version:

Peer reviewed version

Queen's University Belfast - Research Portal:

Link to publication record in Queen's University Belfast Research Portal

Publisher rights

Copyright 2019 Elsevier.

This manuscript is distributed under a Creative Commons Attribution-NonCommercial-NoDerivs License

(https://creativecommons.org/licenses/by-nc-nd/4.0/), which permits distribution and reproduction for non-commercial purposes, provided the author and source are cited.

\section{General rights}

Copyright for the publications made accessible via the Queen's University Belfast Research Portal is retained by the author(s) and / or other copyright owners and it is a condition of accessing these publications that users recognise and abide by the legal requirements associated with these rights.

Take down policy

The Research Portal is Queen's institutional repository that provides access to Queen's research output. Every effort has been made to ensure that content in the Research Portal does not infringe any person's rights, or applicable UK laws. If you discover content in the Research Portal that you believe breaches copyright or violates any law, please contact openaccess@qub.ac.uk. 


\section{Community Treatment Orders and mental health social work: issues for policy and practice in the UK and Ireland}

\section{Introduction: Mental health social work and compulsory powers}

This paper uses a comparative approach to critically analyse the development of the role of the mental health social when CTOs are used three jurisdictions in the UK and where they are not used, in Northern Ireland and a non-UK jurisdiction, the Republic of Ireland. Unlike many jurisdictions in other parts of the world, mental health social workers in the UK (which constitutes the politically devolved jurisdictions of England, Wales, Scotland and Northern Ireland) have substantial, mandated powers in the use of compulsory mental health laws (Campbell et al., 2006). The origins of these roles can be can be traced to a key moment in the history of UK mental health law and policy in the mid to late twentieth century when concerns were raised about the violation of patients' rights in psychiatric hospitals (Fennell, 2002). As a policy response, a period of rapid decarceration occurred and new systems of community based care were designed and delivered. In parallel, three key laws established the mandated role for social workers: the Mental Health Act 1983 for England and Wales; the Mental Health (Scotland) Act 1984 and the Mental Health (Northern Ireland) Order 1986 (see Appendix 1). It was argued that social workers could provide a necessary social perspective to counterbalance the historically powerful position of psychiatry in the mental health system. Social workers were also viewed to be best placed to understand and manage risk in these new community settings, given their skills and knowledge in working with individuals, families and communities (Olsen, 1984). The result was that a cadre of specially trained and educated Approved Social Workers (ASWs), also described as Mental Health Officers (MHOs) in Scotland, were established. Most notably, their key mandated role was to be the applicant, on the advice of a medical recommendation, when citizens were involuntarily admitted to psychiatric hospital. This elevated role can be contrasted with the situation in the Republic of Ireland where social workers can be one of a number of applicants, with limited powers.

In the decades that followed, a number of criticisms emerged about the how successful these laws had been, often predicated on a range of negative social, 
economic and political factors. Thus, not enough of the limited resources allocated to mental health budgets were committed to the type of community-based services that could prevent relapse and readmission to hospital (McDaid and Knapp, 2010). This partly explains the phenomenon of the 'revolving door patient' (Kiesely \& Campbell, 2007). Another problematic issue was the dislocated nature of many mental health services undermined by failures in the creation of joined up health and social care organisations (Cameron et al., 2014). Despite the progressive intentions of these mental health laws, some client groups were more likely to be subject to coercion, including those from ethnic minority communities (Singh et al., 2007). It was also the case that problematic narratives on risk often created difficulties in decision making processes, sometimes compromising the rights of service users (Stanford et al., 2016). It is important therefore to critically analyse the role of the mental health social worker in such circumstances (Campbell, 2009). Ramon (2006) has argued that, by accepting these mandated roles, mental health social workers may be losing key practice skills that paradoxically would be helpful in humanising the experience of clients who were being involuntarily admitted to hospital. In contrast, Morriss (2015) argues that taking on such specialist roles advanced the skills can be utilised to assess need and risk, but realities of resource limitations and difficulties in interdisciplinary and multi-agency working may prevent such opportunities.

The role of the mental health social worker has also been, to some extent, affected by the decentralisation of political powers to the four jurisdictions of the UK; there now tends to be increasing variation in the use of law, policy direction and professional interventions (Davidson et al., 2016). For example, the single professional role of the Mental Health Officer (MHO) has been maintained in Scotland and the ASW in Northern Ireland. In England and Wales, however, the generic Approved Mental Health Professional (AMHP) role now involves social work and non-social work professionals (see Appendix 1). The uptake of the AMHP training by non-social work professions, however, has been low and there is no reliable evidence to indicate any disparity in decision making by professional background (Stone, 2018; Knott and Bannigan, 2013). The introduction of CTOs to England, Wales and Scotland created a number of additional challenges and opportunities for those mental health social workers that, hitherto, were only involved in processes associated with involuntary admissions to hospitals. CTOs were 
designed to deliver less restrictive alternatives in the community, manage risk and prevent relapse and hospitalisation. On the other hand, CTOs may compromise the rights of service users (see, Welsh Ministers v PJ [2017] EWCA Civ 194), often create ethical dilemmas for professionals and yet still not deliver upon the perceived beneficial outcome of avoidance of hospitalisation (Campbell \& Davidson, 2009). Importantly mental health social workers tend to be involved in many of the decisions associated with applications for, and the maintenance of, CTOs. A critical exploration of these issues is given further imperative by the United Nations Convention on the Rights of Person with Disabilities (UNCRPD) and attendant questioning of the legality of compulsion based on mental distress (Minkowitz, 2015). Given the purported value base for social work, and the traditional role of mental health social workers in counter-balancing a medicalised approach, it is therefore important to examine the implications of CTOs for mental health social work practice, now discussed below.

\section{СTOs and the mental health social work role}

The arguments for and against the use of CTOs have already been made elsewhere in this special issue and widely reported in the international literature. CTOs were introduced in England and Wales through the Mental Health Act (2007) as part of a wide-ranging reform of mental health law (Pilgrim \& Ramon, 2009; Cairney, 2009). Community based CTOs have been in operation in Scotland since 2005, following the implementation of the Mental Health (Care and Treatment) (Scotland) Act 2003 (MHSA). Original controversies about the use of CTOs particularly in England and Wales have not dissipated over time, and concerns about their use continue to be raised on both ethical and evidential grounds (Burns \& Molodynski, 2014; Vergunst et al., 2017). Despite the complexity of these decision-making processes, very little has been written about social work practice, and most of what is available examines how mental health law is used in England, and to a lesser extent Scotland and Wales. The paper will now explore what is known about how the introduction of CTOs has affected the profession in England, Wales and Scotland, and the way in which practice is shaped by laws in Northern Ireland and the Republic of Ireland, where CTOs do not exist. 


\section{England and Wales}

Mental health laws and policies in England and Wales are slowly diverging as a result of the devolution process. Yet both nations continue to have a common judicial system, and a patchwork of pre and post-devolution legislation in Wales means that in many areas of mental health law there continues to be continuity across the two nations; this seems to be particularly true in the case of the use of СTOs. One of the issues raised about the operationalisation of CTOs in England and Wales is that a low legal threshold exists compared to CTO regimes in many other jurisdictions (Jobling, 2016), and has recently been identified as an area for potential reform (Department of Health and Social Care, 2018). The single pre-condition is that CTOs can only be applied following compulsory hospitalisation for treatment under sections 3 or 37 of the Mental Health Act 1983. In terms of legal safeguards, all patients subject to a CTO have an automatic right to an Independent Mental Health Advocate (IMHA) who can provide guidance on patient rights and to appeal a CTO either through a Mental Health Review Tribunal (MHRT) or a Hospital Managers' Hearing (legal representation is provided through a system of legal aid). Nearest Relatives (NRs) can also write to a Hospital Manager requesting that their relative be discharged from a CTO, however, this takes up to 72 hours and can be challenged by the Responsible Clinician ( $R C$ ) if it felt that a patient continues to pose a risk to themselves or others.

Despite these safeguards, the broad criteria for the imposition of CTOs also means it can be difficult for these to be discharged. It is hardly surprising, given this issue of low legal threshold that the cumulative rate of usage has grown, however there is a difference in rates of use between England and Wales. The latest figures for CTOs in England place them at 5426, making up 21\% of total uses of the Act in 2016 (Health and Social Care Information Centre, 2016) whilst in Wales 206 CTOs were in place in 2017 , comprising $10 \%$ of total uses of the Act (Statistics for Wales, 2018). As in other parts of the world there is also a stark imbalance in the use of CTOs with black and ethnic minority service users. For example, in England black men are up to eight times more likely to be subject to a CTO than white service users (NHS Digital, 2018). As in Scotland, questions have been raised, not just about the rise in the 
number of CTOs, but also the use of the Mental Health Act more generally. It is worth noting that these concerns have led to a current UK Government review of the Mental Health Act, which has recommended significant reform or even abolition of CTOs (Department of Health and Social Care, 2018; Wessely et al., 2018). In the English and Welsh contexts, mental social workers play a key part in these decisionmaking processes through their role as AMHPs. However, unlike other sections of the Mental Health Act 1983 where AMHPs are central to the process of involuntary admissions to hospital, they are not primary decision-makers about CTOs, but instead act as second opinion for the RC who makes the initial assessment. Yet the agreement of an AMHP is necessary for a CTO to be imposed or renewed, and the RC cannot simply seek the opinion of another AMHP if disagreement occurs. RCs also confer with AMHPs on the nature of conditions which may be attached to a CTO.

There has been little research on the experiences of AMHPs when implementing CTOs, but that which exists suggests they can feel pressured to 'rubber-stamp' CTOs and are not always given enough time to reach a considered decision (Banks, Stroud \& Doughty, 2013). AMHPs have also reported finding it difficult to provide a reason for not agreeing to a CTO; the momentum of hospital discharge combined with the broad legal criteria for CTOs tends to exacerbate this phenomenon (Jobling, 2016). A survey of AMHP decisions on CTOs found that $93 \%$ of CTO requests were agreed by AMHPs, and 90\% of CTO extensions (ADASS, 2018). On the other hand, AMHPs described their role as being more influential in deciding the detail of the CTO, and in particular advocating for the conditions attached to a CTO to ensure that they are realistic and least restrictive. Taylor et al. (2013) found that AMHPs shared a number of sometimes mixed views about the benefits of CTOs. Perceived advantages included prevention of relapse, sometimes through access to housing, but there were concerns that CTOs did not always improve access to important community services, nor deal with aspects of stigma and discrimination. In one stakeholder study (Banks, Stroud \& Doughty, 2016). AMHPs, service users and nearest relatives were asked to comment on how they felt CTOs were delivered, in the context of services that were informed by principles of personalisation. The authors found that, initially, information about legal rights was inadequate and there was relatively little service user involvement in decision making. These processes, 
however, tended to improve when CTOs had been administered and managed carefully. The authors argue that greater involvement by service users in decisionmaking processes may enhance opportunities for recovery.

Social workers are not only involved in the CTO process through the AMHP role, but also, alongside other professionals, as care coordinators. This creates additional, distinct set of ethical dilemmas about how and when to use CTOs. Whilst care coordinators are not formal actors in CTO decision-making, they wield significant informal power over the everyday implementation of CTOs, including monitoring of adherence to CTO conditions and signalling when recall to hospital is deemed necessary. For social workers acting as care coordinators, these aspects of practice imply a contextualised weighing up of the ethical implications of CTOs (Campbell \& Davidson, 2009). Where mental health services are adversely affected by shrinking resources, CTOs may help to ensure that practitioners are prioritising engagement with the service users who are on them (Stroud et al., 2015). Indeed, there is some evidence that CTOs are sometimes being used as a 'short cut' to ensure admission to hospital via recall (Dunn et al., 2016) which can be understood as providing a safety net for service users when bed numbers in England and Wales are reducing (King's Fund, 2015). On the other hand, CTOs can be seen to reinforce and embed medicalised and rote approaches at the expense of psycho-social practice, by both lessening the need for skilled relational work, and foregrounding medical 'containment' via defensive decision-making (Dunn et al., 2016). Indeed, care coordinators in the Stroud, Banks and Doughty (2013) study described how the CTO could damage relationships between them and services users, and at times exacerbate conflict - for example in the requirement for care coordinators to present 'deficit' oriented reports at CTO tribunals. This has clear implications for the position of social workers in the everyday implementation of CTOs and also points to the pressures on practitioners to do 'less with less' in a time of austerity. In this sense, the government's current focus on mental health legislative reform can seem like a distraction from the broader issues that are driving CTO use. Whilst the recent review of mental health law may lead to changes in the CTO regime, it will not necessarily address the reasons why CTOs are being used as they are in England and Wales. The Royal College of Psychiatrists (2018) has recommended to the review that CTOs are grounded in care planning processes which would strengthen 
service user involvement, thus actively addressing the power imbalance inherent to CTOs. Although in theory this may support a more thorough consideration of social needs when CTOs are used, as the Scottish experience discussed below suggests, such a shift may be difficult in the current socio-economic climate.

\section{Scotland}

The Mental Health (Care and Treatment) (Scotland) Act 2003 (MHSA) not only introduced CTOs to Scotland, but also redefined and extended the role of MHOs as key agents in deciding, applying for and implementing CTOs, with social workers generally undertaking a range of related duties conferred on local authorities. The inclusion of CTOs in the MHSA aimed to ensure compliance with the human rights principle of least restriction and reflected a shift towards care at home. At the time they were perceived as controversial but also progressive, as reflected in a series of principles and safeguards enshrined in the MSHA; including rights to advocacy, legal representation and appeal, and, notably, a criterion of 'significantly impaired decision making', aimed at ensuring people with capacity would retain the right to refuse psychiatric treatment. In addition, their inclusion in Scottish legislation followed an extensive and generally well-regarded consultation process that was not hampered by the same political focus on risk as was the case in England and Wales. Thus, while they were met with similar concerns to those for England and Wales, there was a sense of the new legislation and CTOs offering a route to more enlightened mental health practice (Carswell, Donaldson \& Brown, 2007; Scottish Executive, 2001). A study exploring CTO usage in the first six months noted a relatively limited uptake, restricted to revolving door patients (Lawton-Smith, 2006). Since then, however, the number of CTOs has increased significantly, as reflected in the latest statistical report available; rising from 689 in $2008 / 9$ to 956 in 2016. This upturn is mirrored in a sharp increase in the proportion of community to hospital-based CTOs, rising from 4\% in January 2006 to 44.9\% in January 2017 (Mental Welfare Commission, 2018).

Ostensibly, this upward trend in CTOs might be interpreted as evidence of their effectiveness in reducing the practice of treating people in hospital. Hospital based CTOs have, however, also shown a marked increase since the introduction of the MHSA, rising by $22.9 \%$ from 2007 to 2017 (Mental Welfare Commission, 2018). 
Likewise, in Scotland the number of shorter, hospital-based detentions has also risen. Unsurprisingly, therefore, concerns have been expressed about an increase in the use of compulsion in mental health generally and in particular for CTOs, (Mental Welfare Commission, 2015, 2018), and the efficacy of associated safeguards.

Despite their increasing prevalence, there is limited research evidence about CTOs in Scotland, and particularly on the role and views of MHOs and other social workers. The available research includes two Mental Welfare Commission reports that focus largely on service user and carer perspectives, which reveal a qualified sense that CTOs are beneficial and associated care plans are addressing need (Mental Welfare Commission, 2015, 2011). However, key criticisms include a lack of explicit focus on the revocation of CTOs and consideration of how support could be provided on an informal basis, which is seen as having:

"...the potential for practice to become risk averse, and for CTOs to be continued on the basis of a preventative function alone" (MWC, 2015, p.3).

The Mental Welfare Commission (2015) noted that this trend appeared to contradict statutory guidance and suggested that CTOs were being used for longer periods than necessary. Although both reports recognised the value of the work carried out by MHOs (among other professionals), they also found a lack of emphasis on access to social activity and inclusion, elements viewed to be central to the recovery process. These findings offer insights into the ethical and practical dilemmas facing MHOs, social workers and their employers in carrying out their obligations under the Act in respect of CTOs. They point to an inherent tension with professional social work values and the Act's underpinning principles of least restriction and nondiscrimination. The Act sought to address a historical imbalance within mental health provision, which was largely structured around pharmacological treatment, towards acknowledging the importance of social needs. It did so by altering the definition of medical treatment to include: "care and rehabilitation; education, and training in work, social and independent living skills" (MHSA, 2003, S329), and by extending the MHO role. Furthermore, it placed duties on local authorities to promote "wellbeing and social development", including the provision of social, cultural and recreational activities, training and employment and access to travel (ibid, S26 and 
S27). The MWC reports suggest that despite these measures, people's broader social needs are not consistently receiving the attention the MHSA intended.

While the reasons for this are not entirely clear, in part, they may reflect potential contradictions between medical and social model perspectives in defining and addressing mental distress (BASW, 2014). Austerity politics and welfare reform have, however, had a more obvious impact. This is reflected, for example, in the significant reduction in third sector social care services in Scotland (White, 2014) which provide the type of supports that might enable social workers and MHOs to more adequately meet people's wider social and cultural needs. Added to this is the ongoing pressure on $\mathrm{MHO}$ resources in Scotland, as illustrated in a recent regulatory workforce planning report, which detailed a shortfall in MHOs in around two-thirds of local authorities (Scottish Social Services Council, 2017). One indication of impact on staffing levels is the consistently low completion rate of Social Circumstances Reports, a statutory MHO duty that is triggered when certain compulsory measures, including CTOs, are initiated (MWC, 2018). These are critical to assessment processes in providing information to the multidisciplinary team, including an holistic analysis of needs, views, social supports and other relevant factors to inform the development of the person's care plan. The pressures facing MHOs are also intensified by their central role in implementing capacity legislation; here too they have experienced a significant increase in workloads, arising from the upward trend in Guardianship applications in recent years (MWC, 2017).

\section{Northern Ireland}

The next two case studies consider the role of the mental health social worker where CTOs do not exist. As discussed above, CTOs are a relatively recent component of mental health laws in England, Wales and Scotland, but are not present in Northern Ireland and the Republic of Ireland. As part of the Bamford Review of law and policy in this area (Bamford Review, 2007) it was decided that, unlike the rest of the UK, CTOs were not recommended for Northern Ireland. On the other hand, there are some aspects of the current legal framework which do allow compulsory intervention in community settings and the Mental Capacity Act (Northern Ireland) 2016, which is due to be implemented in 2020/21, could widen the scope for compulsory 
intervention (Harper et al., 2016). The current legal framework in Northern Ireland is provided by a combination of the Mental Health (Northern Ireland) Order 1986 and the Common Law. The Mental Health (NI) Order 1986 is a conventional mental health law which allows compulsory admission to hospital based on the criteria of mental disorder and risk to self and/or others.

The ASW has a substantial role in many of the processes associated with the Order (Campbell et al, 2001). Nearly all applications for involuntary admission to hospital are carried out by ASWs and must be accompanied by a medical recommendation. Although the focus of the law is hospital care it also provides for Guardianship which is designed for community settings although again based on the criteria of mental disorder and risk. ASWs also play key roles in these processes. The only comprehensive study of the role of the ASW in Northern Ireland (Manktelow et al, 2002) revealed a number of interesting decision-making dilemmas and organisational challenges. There was considerable variation in the expertise of ASWs, some difficulties in the relationship with GPs during the assessment process, yet generally high levels of perceived competence and confidence in using the legislation. A later audit of ASW assessments (Davidson and Campbell, 2009) found inconsistencies in how assessments were recorded and some problems with the inter-agency working which is crucial for these processes. Most ASWs were positive about the possible introduction of CTOs, in order to try to prevent relapse and the need for admission, but they did also identify some of the ethical complexities involved.

The powers of Guardianship are to: require the person to reside in a certain place; attend for (not necessarily accept) care and/or treatment; and allow access, usually to the relevant mental health team. If a person does not comply with these requirements there is no additional process to promote compliance, although an assessment to consider the criteria for hospital admission may be considered. These community powers are rarely used, with approximately 40-60 people being subject to Guardianship at any one time. Whilst a new, 'fused' law is delayed (Mental Capacity Act (Northern Ireland) 2016) where issues of capacity are evident then intervention proceeds, based on the Common Law. Mental health professionals then must have a reasonable belief the person lacks the capacity to make the decision and the proposed intervention is in their best interests. If the proposed intervention in the 
community amounts to deprivation of liberty then, based on the Bournewood Case ( $H L \vee$ the United Kingdom), this should require an application to the High Court for a declaratory order. It has been argued that this rarely occurs, perhaps because the court system is not currently resourced to consider all such cases (Davidson et al., 2016). It is interesting to note the pattern of the use of compulsory powers when compared to other jurisdictions in the UK. For example, in England the number of detentions in hospital has moved from 48,631 in 2011/12 to 63,622 in 2015/16, an increase of 14,991 or $31 \%$. In Northern Ireland over the same period the number of detentions also grew from 992 in 2011/12 to 1070 in 2015/16, an increase of 78 or $8 \%$. This also reflects a difference in rate per 100,000 in 2015/16 of 115.7 in England (Keown et al., 2018) and 57 in NI. In the same period the number of new CTOs in England also increased from 4220 to 4361 (Gupta et al., 2018) and the number of Deprivation of Liberty Safeguards applications increased from 11,380 to 105,055 (Health and Social Care Information Centre, 2016).

The Mental Capacity Act (Northern Ireland) 2016 will not introduce CTOs in the conventional sense but it will replace the Mental Health (NI) Order 1986 and provide a comprehensive legal framework for interventions when a person lacks the capacity, for whatever reason, to make the relevant decision. This, in practice, will include compulsory treatment in community settings, for example as a result of other causes of impairment including alcohol and drug use. One of the guiding principles of the new Act is that any proposed intervention must be in the person's best interests with special regard being given to the person's past and present wishes and feelings. Although there is some debate about the retention of the phrase 'best interests' (Kelly, 2015) it would seem reasonable to assume that this should include consideration of whether the proposed intervention is effective or, at least, not harmful. Arguably, the international evidence on the effectiveness of CTOs is not sufficient to suggest that, in most cases, it would be in the person's best interests to impose the equivalent intervention/s to a CTO. It has been argued that the central potential benefit of a CTO is that it ensures ongoing follow-up by services. One possible response to the concerns about the focus of ineffective, and potentially negative, compulsory powers on the well-being of service users could entail a shift the focus of compulsion to the service provider to ensure the person is at least offered ongoing support. The Code of Practice for the new Act is currently being 
drafted and so could provide further guidance on how these issues should be considered in determining what is in the person's best interests.

\section{Republic of Ireland}

Since the partition of Ireland in 1921, mental health policy and practice in the Republic has been shaped by the political and social mores of society and politics and policy drivers that have created some divergence from the UK case studies discussed above. It has been argued that the modernisation of services and mental health law, took longer, caused by a range of factors, including the State's laissez faire approach to provision and, until the late twentieth century, funding restrictions (Kelly, 2004; Higgins \& McDaid (eds.), 2014). It was not until the introduction of the Mental Health Act, 2001, that the rights of patients became adequately protected. New safeguards included more rigorously monitored processes for involuntary admission and detention, quick access to, and legal representation at mental health review tribunals and the creation of a mental health commission with inspectorial powers (Kelly, 2007). There has been a steady increase of involuntary admissions from 2141 to 2414 for the period 2012-2016, although in 2017 there was a decrease of $3 \%$ (Mental Health Commission, 2017). Of particular note has been a continuing reduction in the use of family members as applicants, from $69 \%$ in 2007 to $44 \%$ in 2017. This is a trend that is being advocated for by the Mental Health Commission. Although the law generally adheres to conventional human rights standards, it can be argued that the involvement of family members in this way is resonant of older UK mental health laws that predate the changes of the 1980s. Unlike the situation in England, Wales and Scotland, there is no provision for CTOs. In a recent debate on the subject (McDonald et al., 2017), two opposing positions were taken. Powers exist under Section 26 of the Mental Health Act, 2001 that allow a degree of coercion in the community. For example, these require patients to adhere to medication regimes or reside in certain settings. This form of approved leave they describe as a surrogate, or 'quasi community treatment orders'. A more transparent, legally based form of CTO, with extensive safeguards, it has been argued, should be introduced to the Republic of Ireland to ensure that patients have a right to such forms of care, and control, in the community in order to realise the least restrictive option. A contrary 
point of view is that the evidence base to support a therapeutic argument for CTOs is difficult to sustain (Lally, 2013) and concerns remain that, if introduced to Ireland 'legislative creep' will occur and excessive, sometimes unregulated use of professional powers become hard to resist.

For better or for worse, the position of social work in mental health law is relatively peripheral, compared to the other jurisdictions considered in this paper. In this respect the current law more resembles the UK laws that existed before the 1980s where social workers became involved in involuntary admissions, but only where the NR is not available. In the UK the advent of ASWs, MHOs and AMHPs has largely displaced a decision making function for relatives; the removal of family members from this role is widely regarded to be more protective of the rights and needs of both carers and patients. However, the Mental Health Act, 2001 created the concept of the Authorised Officer ( $\mathrm{AO}$ ) which allows this function to be carried out by a range of people, including mental health social workers. Statistics on the characteristics of AOs reinforce a perception that social workers have a relatively minor influence on decision-making process simply because they are less likely than relatives, police and other persons to make applications for involuntary admissions. Browne (2015) has explained how statutory agencies in Ireland, including the Mental Health Commission and the Health Service Executive have lobbied for a greater role for mental health professionals, including social workers, but problems of training and uptake of the roles has prevented such developments. As in other jurisdictions, however, mental health social workers are centrally involved in many aspects of service provision and decision-making, for example in discharge planning and deliberations in multidisciplinary teams when issues of risk management and care considered in these contexts.

\section{Discussion}

There are a number of themes that have emerged from the literature and analysis of the case studies presented in this paper. In general the use of compulsion presents a major challenge for mental health social workers as, by definition, this involves imposing interventions that often compromise the rights of service users; this may be problematic given social work's attention to the fundamental importance of 
relationships, and how building such relationships with service users can enhance autonomy, rights, recovery and the wider family and social system. It was argued that, in the UK, policy makers introduced specialist mandated roles in the 1980s to compensate for the predominance of the medical opinion when compulsory powers were being used. Disputes remain about whether this counterbalance in decisionmaking has been achieved, particularly given the relative paucity of evidence on the role of social workers in the use of mental laws.

If anything the introduction of CTOs has made it even more imperative that the social work role is better understood, given the contentious nature of this form of compulsion (Brophy, L., Ryan, C. J., \& Weller, P., 2018; Puntis, Rugkasa \& Burns, 2017; MWC, 2011; Burns \& Molodynski, 2014; Burns et al., 2015). The consistent rise in the use of CTOs in the UK, mirrors trends in other international jurisdictions. It is often the case that increased use arises because of limited community based resources, an apparently perverse outcome for an instrument that was designed to be used in limited, restricted circumstances and is at variance with the direction of international law. The issue of relatively low thresholds, described earlier, also contributes to this unintended effect. Meanwhile mental health social workers increasingly intervene using a mix of coercive and supportive approaches, whether mandated as in the case studies of England, Wales and Scotland, or where CTOs are not used, in Northern Ireland and the Republic of Ireland.

The review of the case studies revealed the complexities of the mental health social work role which varies, depending upon jurisdiction. In Britain (England, Wales and Scotland) social workers are both involved in legal decision-making on CTOs, and perhaps more importantly, managing risk and care in the community when CTOs are being used. This often 'hidden' aspect of practice is characterised by a number of contradictions. The intention to provide supportive relationships with service users to deliver the least restrictive alternative in the form of the CTO is often compromised by a lack of resources and the tendency to default to medication only regimes, despite the attempts by policy makers to provide appropriate services. When a service user's resists the purpose and practices involved in the management and delivery of CTOs then relational-based social work can often become more challenging. This in turn may limit the ability of mental health social workers to gain to the social and financial resources that are available. Given that a central aspect of 
the mental health social work role is to mediate between an individual, their family and broader social supports/networks in order to promote inclusion (Allen et al, 2016), the potential for the CTO to constrain this work is problematic for effective and ethical social work practice. A key factor that affects outcomes in this field has been the effects of a decade of economic austerity, resulting in failures to deliver the broader aspirations for social inclusion, implied by the CTO (Mental Welfare Commission, 2015). Much of the evidence suggests that coherent care planning can improve the chances for the success of CTOs, and mental health social workers view this as an area of specialism, but in its absence, there will be a retreat to coercion, and eventually an expedited return to hospital. Perhaps now is the time to shift the locus of legal responsibility, from individual practitioners and service users to providers via a robust requirement for reciprocity, when, as is often the case, necessary resources are not made available.

One aspect of the research literature which does support and reinforce the rights and recovery focused approach of mental health social work can be found in procedural justice approaches (Galon and Wineman, 2010). Across studies, findings confirm that the way that compulsion is operationalised can have an impact on how traumatic and coercive it feels for the service user. Involving the person in the decision making process, explaining all the relevant information and listening to them are all required to promote people's rights, for example under Article 6 of the ECHR, but this research evidence suggests that it is also important to outcomes. In Northern Ireland and the Republic of Ireland, where CTOs do not exist, other forms of control and decision-making in the use of compulsion are evident. Questions remains as to whether the more explicit mandated role in England, Wales and Scotland, is more protective of human rights. When CTOs are not part of mental health legislation, but an alternative version of community based coercion then a number of different practice demands, often more obscured, may affect mental health social work practice. For example in Ireland, on both sides of the border, arrangements for conditional discharge appear loose and difficult to define and regulate in a way that, at least in principle, CTOs can be. Generally, in the absence of CTOs, social workers, alongside other mental health professionals become immersed in calculations about using subtle forms of coercion which are not necessarily regulated 
(Campbell \& Davidson, 2009). Consequently, service user rights to fair and transparent treatment can be lost.

Finally, it is important to view such discussions about the mental health social work role in the situation of wider debates about law and human rights. It may be that we can conclude that it is not the CTO that is the issue, rather a more fuller investigation of current paradigms on mental health law is needed. As Lynch, Taggart and Campbell (2017) note, no UK mental health legislation meets the requirements of the UNCRPD. decision-making processes remain complex and potentially contradictory at the interfaces between capacity and community care laws in England, Scotland and Wales. In these case examples missing safeguards such as the patient's right to refuse treatment and problems of defining the capacity criteria often create difficulties in assessment and care planning for mental health social workers and other professionals. The effect may be that paternalistic attitudes towards involuntary treatment remain (Fistein, 2009). The fused legislation proposed for Northern Ireland, however may go some way to meeting the UNCRPD standards, not only in terms of how issues of capacity are treated, but also in terms of mechanisms such as powers of attorney and advanced decision-making can be protective of service user rights. The recent review of mental health laws in England and Wales (Department of Health and Social Care, 2018), while stopping short of the 'fusion' model, seeks to rebalance legislation in favour of service user rights. Specifically, the review made a number of recommendations for the reform of CTOs, including a more rigorous set of pre-conditions for their use, and a time limit of two year and a target of a $50 \%$ reduction in two years. A move towards more rights-based mental health laws UK and Irish jurisdictions may support mental health social work practice in operationalising legal and policy frameworks that are more aligned to the professional's ethical principles and the social model of mental health. However, without each governments' comittments to adequately resourced community based service CTO practices will often remain problematic and contradictory.

\section{Conclusion}

It has been argued in this paper the introduction of CTOs to the UK have inevitably raised a range of complex decision-making dilemmas that affect mental health social 
work practice; these have been made more problematic by the absence of a consensus about the purpose and efficacy of CTOs. The case studies reveal diversity in the legal processes that involve mental health social workers, both when CTOs are, and are not available. In delineating a wide range of complex factors that affect the social worker role, this paper also identifies a significant research gap relating to their views and contributions regarding CTOs and associated coercive forms of community mental health care and treatment. There remain relatively few studies on social work practice and CTOs within individual UK jurisdictions, and none which undertake a comparative analysis across jurisdictions. Both the commonalities and disparities raised here suggest further investigation of this kind is need, especially within the context of forthcoming changes to legislation and policy frameworks within these and other jurisdictions.

\section{References}

Allen, R. Carr, S., Linde, K. and Sewell, H. (2016). Social Work for Better Mental Health: A Strategic Statement. London: Department of Health.

Bamford Review (2007). A comprehensive legislative framework. Belfast: Bamford Review of Mental Health and Learning Disability (Northern Ireland).

Banks, L. C., Stroud, J., \& Doughty, K. (2016). Community treatment orders: exploring the paradox of personalisation under compulsion. Health \& social care in the community, 24(6), e181-e190.

Bressington, D. T., Wells, H., \& Graham, M. (2011). A concept mapping exploration of social workers' and mental health nurses' understanding of the role of the Approved Mental Health Professional. Nurse Education Today, 31(6), 564-570.

Brophy, L., Ryan, C. J., \& Weller, P. (2018). Community treatment orders. Critical Perspectives on Coercive Interventions: Law, Medicine and Society in Spivakovsky, C., Seear, K., \& Carter, A. (Eds.). (2018). Critical Perspectives on Coercive Interventions: Law, Medicine and Society. Routledge.

Browne, F. J. (2015). The development of the role in Ireland of the Authorised Officer (Section 9: 1b Mental Health Act 2001) applicant for the involuntary admission to 
approved centres of persons suffering from mental disorders. Irish Journal of Psychological Medicine, 32(4), 353-358.

Burns, T., \& Molodynski, A. (2014). Community treatment orders: background and implications of the OCTET trial. The Psychiatric Bulletin, 38, 3-5.

Burns, T., Yeeles, K., Koshiaris, C., Vazquez-Montes, M., Molodynski, A., Puntis, S., ... \& Rugkåsa, J. (2015). Effect of increased compulsion on readmission to hospital or disengagement from community services for patients with psychosis: follow-up of a cohort from the OCTET trial. The Lancet Psychiatry, 2(10), 881-890.

Cairney, P. (2009). The British policy style and mental health: Beyond the headlines. Journal of Social Policy, 38, 671-688.

Cameron, A., Lart, R., Bostock, L., \& Coomber, C. (2014). Factors that promote and hinder joint and integrated working between health and social care services: a review of research literature. Health \& social care in the community, 22(3), 225-233.

Campbell, J., Wilson, G., Britton, F., Hamilton, B., Hughes, P., \& Manktelow, R. (2001). The management and supervision of Approved Social Workers: Aspects of law, policy and practice. The Journal of Social Welfare \& Family Law, 23(2), 155172.

Campbell, J., Brophy, L. Healy, B. \& O'Brien, AM. (2006). International perspectives on the use of community treatment orders: Implications for mental health social workers. British Journal of Social Work 36, 7: 1101-1118.

Campbell, J. (2009). Deciding to detain: the use of compulsory mental health law by UK social workers. British Journal of Social Work, 40(1), 328-334.

Campbell, J., \& Davidson, G. (2009). Coercion in the community: a situated approach to the examination of ethical challenges for mental health social workers. Ethics and Social Welfare, 3, 249-263.

Campbell, J., Brophy, L., Davidson, G., \& O'Brien, A. M. (2018). Legal capacity and the mental health social worker role: an international comparison. Journal of Social Work Practice, 32(2), 139-152. 
Carswell, C., Donaldson, A. \& Brown,K. (2007). Psychiatrists' views and experiences of the Mental Health (Care and Treatment) (Scotland) Act 2003. Psychiatric Bulletin, 31, 83-85.

Coyle, D., Macpherson, R., Foy, C., Molodynski, A., Biju, M., \& Hayes, J. (2013). Compulsion in the community: mental health professionals' views and experiences of CTOs. The Psychiatrist Online, 37(10), 315-321.

Davidson, G., Brophy, L., Campbell, J., Farrell, S. J., Gooding, P., \& O'Brien, A. M. (2016). An international comparison of legal frameworks for supported and substitute decision-making in mental health services. International journal of law and psychiatry, 44, 30-40.

Davidson, G., \& Campbell, J. (2009). An audit of assessment and reporting by Approved Social Workers (ASWs). British Journal of Social Work, 40(5), 1609-1627.

Department of Health and Social Care. (2018). Modernising the Mental Health Act Increasing choice, reducing compulsion Final report of the Independent Review of the Mental Health Act 1983. Available at:

https://assets.publishing.service.gov.uk/government/uploads/system/uploads/attach ment_data/file/762206/MHA_reviewFINAL.pdf (Accessed 10.12.18)

Dunn, M., Canvin, K., Rugkasa, J., Sinclair, J. \& Burns, T. (2016). An empirical ethical analysis of community treatment orders within mental health services in England. Clinical Ethics, 11(4), 130-139.

Fennell, P. (2002). Treatment without consent: Law, psychiatry and the treatment of mentally disordered people since 1845 . London: Routledge.

Fistein, E.C., Holland, A.J., Clare, I.C.H., \& Gunn, M.J. (2009). A comparison of mental health legislation from diverse Commonwealth jurisdictions. International Journal of Law and Psychiatry. 32, 147-155.

Gupta, S., Akyuz, E. U., Baldwin, T., \& Curtis, D. (2018). Community treatment orders in England: review of usage from national data. BJPsych bulletin, 42(3), 119122. 
Harper, C., Davidson, G., \& McClelland, R. (2017). No longer 'anomalous, confusing and unjust': the Mental Capacity Act (Northern Ireland) 2016. International Journal of Mental Health and Capacity Law, 2016(22), 57-70.

Health and Social Care Information Centre (2016) Mental Capacity Act (2005) Deprivation of Liberty Safeguards (England). Leeds: NHS Digital.

Health and Social Care Information Centre. (2016). Inpatients formally detained in hospitals under the Mental Health Act 1983, and patients subject to supervised community treatment, Annual figures, England, 2015/16. London: Government Statistical Service.

Higgins, A., \& McDaid, S. (Eds.). (2014). Mental Health in Ireland: Policy, Practice \& Law. Dublin: Gill \& Macmillan.

Jobling, H. (2014). Using ethnography to explore causality in mental health policy and practice. Qualitative social work, 13(1), 49-68.

Jobling, H. (2016). Local policy in a global context: regimes of risk in mental health policy and practice - the case of community treatment orders. In T. Evans \& F. Keating (Eds.), Policy and Social Work Practice (pp. 151-171. London: Sage. The King's Fund (2015). Briefing: Mental Health under Pressure. London: The King's Fund.

Kelly, B. D. (2004). Mental health policy in Ireland 1984-2004: theory, overview and future directions. Irish Journal of Psychological Medicine, 21(2), 61-68.

Kelly, B. D. (2007). The Irish mental health act 2001. Psychiatric Bulletin, 31(1), 2124.

Kelly, B. D. (2015). Best interests, mental capacity legislation and the UN Convention on the Rights of Persons with Disabilities. BJPsych Advances, 21(3), 188-195.

Kisely, S., \& Campbell, L. A. (2007). Does compulsory or supervised community treatment reduce 'revolving door'care?: Legislation is inconsistent with recent evidence. The British Journal of Psychiatry, 191(5), 373-374. 
Knott, G. and Bannigan, K., 2013. A Critical Review of the approved mental health professional role and occupational therapy. British Journal of Occupational Therapy, 76(3), pp.118-126.

Lally, J. (2013). Liberty or dignity: Community treatment orders and rights. Irish Journal of Psychological Medicine, 30(2), 141-149.

Lawton-Smith, S. (2006). Community-based Compulsory Treatment Orders in Scotland: The Early Evidence, King's Fund, London.

Lynch, G., Taggert, C. \& Campbell, P. (2017). Mental Capacity Act (Northern Ireland) 2016. British Journal of Psychiatry Bulletin, 41(6), 353-357.

Manktelow, R., Hughes, P., Britton, F., Campbell, J., Hamilton, B., \& Wilson, G. (2002). The experience and practice of approved social workers in Northern Ireland. British Journal of Social Work, 32(4), 443-461.

Mental Health Commission (2017). Annual Report, Dublin: MHC.

Mental Welfare Commission (2011). Lives Less Restricted: A report into the use of compulsory community treatment in Scotland. Edinburgh: Mental Welfare Commission.

Mental Welfare Commission (2015). Visit and Monitoring Report: Visits to people on longer term community-based compulsory treatment orders. Edinburgh: Mental Welfare Commission.

Mental Welfare Commission (2018). Statistical Monitoring: Mental Health Act monitoring report 2016-17. Edinburgh: Mental Welfare Commission.

McDaid, D., \& Knapp, M. (2010). Black-skies planning? Prioritising mental health services in times of austerity. The British Journal of Psychiatry, 196(6), 423-424. McDonald, C., O'Reilly, R., Kelly, B. D., \& Burns, T. (2017). Community treatment orders should be introduced in the Republic of Ireland. Irish Journal of Psychological Medicine, 34(4), 295-303.

Minkowitz, T. (2015). Advancing the rights of users and survivors of psychiatry using the UN Convention on the Rights of Persons with Disabilities, in Spandler, H., 
Anderson, J. and Sapey, B. (2015) (Eds) Madness, Distress and the Politics of Disablement. Bristol: Policy Press.

Molodynski, A., Puntis, S., \& Rugkåsa, J. (2015). Effect of increased compulsion on readmission to hospital or disengagement from community services for patients with psychosis: follow-up of a cohort from the OCTET trial. The Lancet Psychiatry, 2(10), 881-890.

Morriss, L., 2015. AMHP work: Dirty or prestigious? Dirty work designations and the approved mental health professional. The British Journal of Social Work, 46(3), pp.703-718.

NHS Digital (2018). Mental Health Act Statistics, Annual Figures 2017-18. Available at: https://digital.nhs.uk/data-and-information/publications/statistical/mental-healthact-statistics-annual-figures/2017-18-annual-figures(Accessed 10.12.18)

Olsen, M. R. (Ed.). (1984). Social work \& mental health: a guide for the approved social worker (Vol. 269). London: Taylor \& Francis.

Pilgrim, D., \& Ramon, S. (2009). English mental health policy under New Labour. Policy \& Politics, 37, 273-288.

Puntis, S. R., Rugkåsa, J., \& Burns, T. (2017). Associations between compulsory community treatment and continuity of care in a three year follow-up of the Oxford Community Treatment Order Trial (OCTET) cohort. BMC psychiatry, 17(1), 151.

Ramon, S. (2006). British mental health social work and the psychosocial approach in context. Critical psychiatry (pp. 133-148). London: Palgrave Macmillan.

Royal College of Psychiatrists (2018). Review of the Mental Health Act 1983. The Royal College of Psychiatrists' Submission of Evidence. London: RCPsych.

Rugkåsa, J., \& Burns, T. (2017). Community treatment orders: are they useful?. BJPsych Advances, 23(4), 222-230.

Scottish Executive (2001) New Directions: Report on the Review of the Mental Health (Scotland) Act 1984. Edinburgh: Scottish Executive. 
Singh, S. P., Greenwood, N. A. N., White, S., \& Churchill, R. (2007). Ethnicity and the Mental Health Act 1983: systematic review. The British Journal of Psychiatry, 191(2), 99-105.

Statistics for Wales (2018). Admission of patients to mental health facilities in Wales, 2016-17. Cardiff: Statistical First Release 11/2018.

Stone, K., 2018. Approved Mental Health Professionals and Detention: An Exploration of Professional Differences and Simularities. Practice, pp.1-14.

Stroud, J., Doughty, K., \& Banks, M. L. (2013). An Exploration of Service User and Practitioner Experiences of Community Treatment Orders. London: National Institute for Health Research.

Taylor, J.A., Lawton-Smith, S. \& Bullmore, H. (2013). Supervised community treatment: does it facilitate inclusion? A perspective from approved mental health professionals (AMHPs). Mental Health and Social Inclusion, 17(1), 157-164.

The King's Fund (2015). Briefing: Mental Health under Pressure. London: The King's Fund.

Vergunst, F., Rugkasa, J., Koshiaris, C., Simon, J., \& Burns, T. (2017). Community treatment orders and social outcomes for patients with psychosis: a 48-month followup study. Social Psychiatry and Psychiatric Epidemiology, 52, 1375-1384.

Wessely, S., Glibert, S., Hedley, M., \& Neuberger, J. (2018). The Independent Review of the Mental Health Act: Interim Report. London: Department of Health and Social Care. 


\section{Appendix 1}

\begin{tabular}{|c|c|c|c|c|c|}
\hline Themes & England & Wales & Scotland & $\begin{array}{l}\text { Northern } \\
\text { Ireland }\end{array}$ & $\begin{array}{l}\text { Republic of } \\
\text { Ireland }\end{array}$ \\
\hline $\begin{array}{l}\text { Previous mental } \\
\text { health laws }\end{array}$ & $\begin{array}{l}\text { Mental Health } \\
\text { Act } 1983\end{array}$ & $\begin{array}{l}\text { Mental } \\
\text { Health Act } \\
1983\end{array}$ & $\begin{array}{l}\text { Mental Health } \\
\text { (Scotland) Act } \\
1984\end{array}$ & $\begin{array}{l}\text { Mental } \\
\text { Health Order } \\
1986\end{array}$ & $\begin{array}{l}\text { Mental } \\
\text { Treatment } \\
\text { Health Act } \\
1948 \\
\end{array}$ \\
\hline $\begin{array}{l}\text { Contemporary } \\
\text { mental health laws }\end{array}$ & $\begin{array}{l}\text { Mental Health } \\
\text { Act, } 2007 \\
\text { Mental } \\
\text { Capacity Act } \\
2005\end{array}$ & $\begin{array}{l}\text { Mental } \\
\text { Health } \\
\text { (Wales) } \\
\text { Measure } \\
2010, \\
\text { Mental } \\
\text { Health Act } \\
2007, \\
\text { Mental } \\
\text { Capacity Act } \\
2005\end{array}$ & $\begin{array}{l}\text { Mental Health } \\
\text { (Care and } \\
\text { Treatment) } \\
\text { (Scotland) Act } \\
2003 \text { Mental } \\
\text { Health } \\
\text { (Scotland) Act } \\
2015 \\
\text { Adults with } \\
\text { Incapacity } \\
\text { (Scotland) Acts } \\
2000\end{array}$ & $\begin{array}{l}\text { Mental } \\
\text { Capacity Act } \\
\text { Northern } \\
\text { Ireland } 2016 \\
\text { (not yet } \\
\text { implemented) }\end{array}$ & $\begin{array}{l}\text { Mental } \\
\text { Health Act, } \\
2001 \\
\text { Assisted } \\
\text { Decision- } \\
\text { Making } \\
\text { (Capacity) } \\
\text { Act, } 2017\end{array}$ \\
\hline $\begin{array}{l}\text { Mental health } \\
\text { social work } \\
\text { roles }\end{array}$ & $\begin{array}{l}\text { Approved } \\
\text { Mental Health } \\
\text { Professionals }\end{array}$ & $\begin{array}{l}\text { Approved } \\
\text { Mental } \\
\text { Health } \\
\text { Professionals }\end{array}$ & $\begin{array}{l}\text { Mental Health } \\
\text { Officers }\end{array}$ & $\begin{array}{l}\text { Approved } \\
\text { Social } \\
\text { Workers }\end{array}$ & $\begin{array}{l}\text { Authorised } \\
\text { Officers }\end{array}$ \\
\hline $\begin{array}{l}\text { Role of social } \\
\text { workers in the use } \\
\text { of CTOs }\end{array}$ & $\begin{array}{l}\text { Approved } \\
\text { Mental Health } \\
\text { Professionals as } \\
\text { secondary } \\
\text { decision- } \\
\text { makers in } \\
\text { applying and } \\
\text { renewing CTOs, } \\
\text { and agreeing } \\
\text { conditions. } \\
\text { If care } \\
\text { coordinator, } \\
\text { mental health } \\
\text { social workers } \\
\text { instrumental in } \\
\text { 'day to day' } \\
\text { implementation } \\
\text { of CTOs - } \\
\text { including } \\
\text { monitoring of } \\
\text { conditions and } \\
\text { requesting } \\
\text { recall. }\end{array}$ & $\begin{array}{l}\text { As in } \\
\text { England } \\
\text { (AMHP } \\
\text { involvement } \\
\text { only) }\end{array}$ & $\begin{array}{l}\text { Mental Health } \\
\text { Officers play a } \\
\text { key role in } \\
\text { applying for } \\
\text { CTOs. Together } \\
\text { with mental } \\
\text { health social } \\
\text { workers they } \\
\text { are also } \\
\text { mandated to } \\
\text { contribute to } \\
\text { the ongoing } \\
\text { implementation } \\
\text { and review of } \\
\text { CTOs. }\end{array}$ & $\begin{array}{l}\text { CTOs not } \\
\text { available } \\
\text { under the } \\
\text { current law }\end{array}$ & $\begin{array}{l}\text { CTOs are not } \\
\text { available } \\
\text { under the } \\
\text { current law }\end{array}$ \\
\hline $\begin{array}{l}\text { Multidisciplinary } \\
\text { working }\end{array}$ & $\begin{array}{l}\text { AMHP plus } \\
\text { Responsible } \\
\text { Clinician. } \\
\end{array}$ & $\begin{array}{l}\text { As in } \\
\text { England }\end{array}$ & $\begin{array}{l}\text { MHO plus } \\
\text { Responsible } \\
\text { Medical Officer }\end{array}$ & $\begin{array}{l}\text { ASW plus GP } \\
\text { or other } \\
\text { medic }\end{array}$ & $\begin{array}{l}\text { Discharge } \\
\text { care co- } \\
\text { ordination, }\end{array}$ \\
\hline
\end{tabular}




\begin{tabular}{|c|c|c|c|c|c|}
\hline & & & & & $\begin{array}{l}\text { but weak } \\
\text { mandated } \\
\text { role }\end{array}$ \\
\hline $\begin{array}{l}\text { Organisational and } \\
\text { practice dilemmas }\end{array}$ & $\begin{array}{l}\text { Problems in } \\
\text { integration of } \\
\text { health and } \\
\text { social care } \\
\text { services } \\
\text { Pressures to } \\
\text { 'rubber-stamp' } \\
\text { formal } \\
\text { decisions } \\
\text { Constraints on } \\
\text { relational and } \\
\text { socially } \\
\text { oriented } \\
\text { practices. } \\
\text { Increasing } \\
\text { expectations } \\
\text { for service user } \\
\text { voices in use of } \\
\text { compulsory } \\
\text { powers with } \\
\text { current review } \\
\text { of mental } \\
\text { health law } \\
\text { foregrounding } \\
\text { service user } \\
\text { perspectives. }\end{array}$ & $\begin{array}{l}\text { As in } \\
\text { England }\end{array}$ & $\begin{array}{l}\text { Multi- } \\
\text { disciplinary } \\
\text { working and } \\
\text { resource } \\
\text { constraints. } \\
\text { Availability of } \\
\text { alternatives to } \\
\text { compulsion. }\end{array}$ & $\begin{array}{l}\begin{array}{l}\text { Complexities } \\
\text { of inter- } \\
\text { agency } \\
\text { coordination. }\end{array} \\
\text { Availability of } \\
\text { beds and } \\
\text { alternatives } \\
\text { to } \\
\text { compulsion. } \\
\text { Variations in } \\
\text { recording and } \\
\text { monitoring. } \\
\text { Availability of } \\
\text { legal } \\
\text { advocacy. }\end{array}$ & $\begin{array}{l}\text { Interface } \\
\text { between } \\
\text { state and } \\
\text { voluntary } \\
\text { sector } \\
\text { organisations } \\
\text { The possible } \\
\text { use of } \\
\text { coercion in } \\
\text { the } \\
\text { community } \\
\text { without a } \\
\text { defined, } \\
\text { mandated } \\
\text { role }\end{array}$ \\
\hline $\begin{array}{l}\text { Future policy and } \\
\text { practice }\end{array}$ & $\begin{array}{l}\text { Interface with } \\
\text { capacity laws } \\
\text { Reform of } \\
\text { mental health } \\
\text { law: } \\
\text { (i) CTOs are } \\
\text { subject to legal } \\
\text { challenge; } \\
\text { (ii) reduction in } \\
\text { usage followed } \\
\text { by review; (iii) } \\
\text { addressing low } \\
\text { threshold } \\
\text { issues; (iv) } \\
\text { review of } \\
\text { criteria for } \\
\text { detention; (v) }\end{array}$ & $\begin{array}{l}\text { As in } \\
\text { England, } \\
\text { MCA } \\
\text { reforms will } \\
\text { be } \\
\text { significant. }\end{array}$ & $\begin{array}{l}\text { The Mental } \\
\text { Health } \\
\text { (Scotland) Act } \\
2015 \text { offered a } \\
\text { very limited } \\
\text { review of the } \\
2003 \text { Act. } \\
\text { Current focus is } \\
\text { on wholesale } \\
\text { revision of } \\
\text { capacity } \\
\text { legislation after } \\
\text { which more } \\
\text { substantive } \\
\text { changes to } \\
\text { mental health } \\
\text { law is } \\
\text { envisaged. }\end{array}$ & $\begin{array}{l}\text { Delay in the } \\
\text { introduction } \\
\text { of the Mental } \\
\text { Capacity Act, } \\
\text { Northern } \\
\text { Ireland, } 2016\end{array}$ & $\begin{array}{l}\text { Delay in the } \\
\text { delivery of } \\
\text { the Assisted } \\
\text { Decision- } \\
\text { Making Act, } \\
2017 \\
\text { Reform of } \\
\text { the Mental } \\
\text { Health Act, } \\
2001 \text { to } \\
\text { allow greater } \\
\text { access to } \\
\text { mental } \\
\text { health } \\
\text { review } \\
\text { tribunals, } \\
\text { removal of } \\
\text { best }\end{array}$ \\
\hline
\end{tabular}




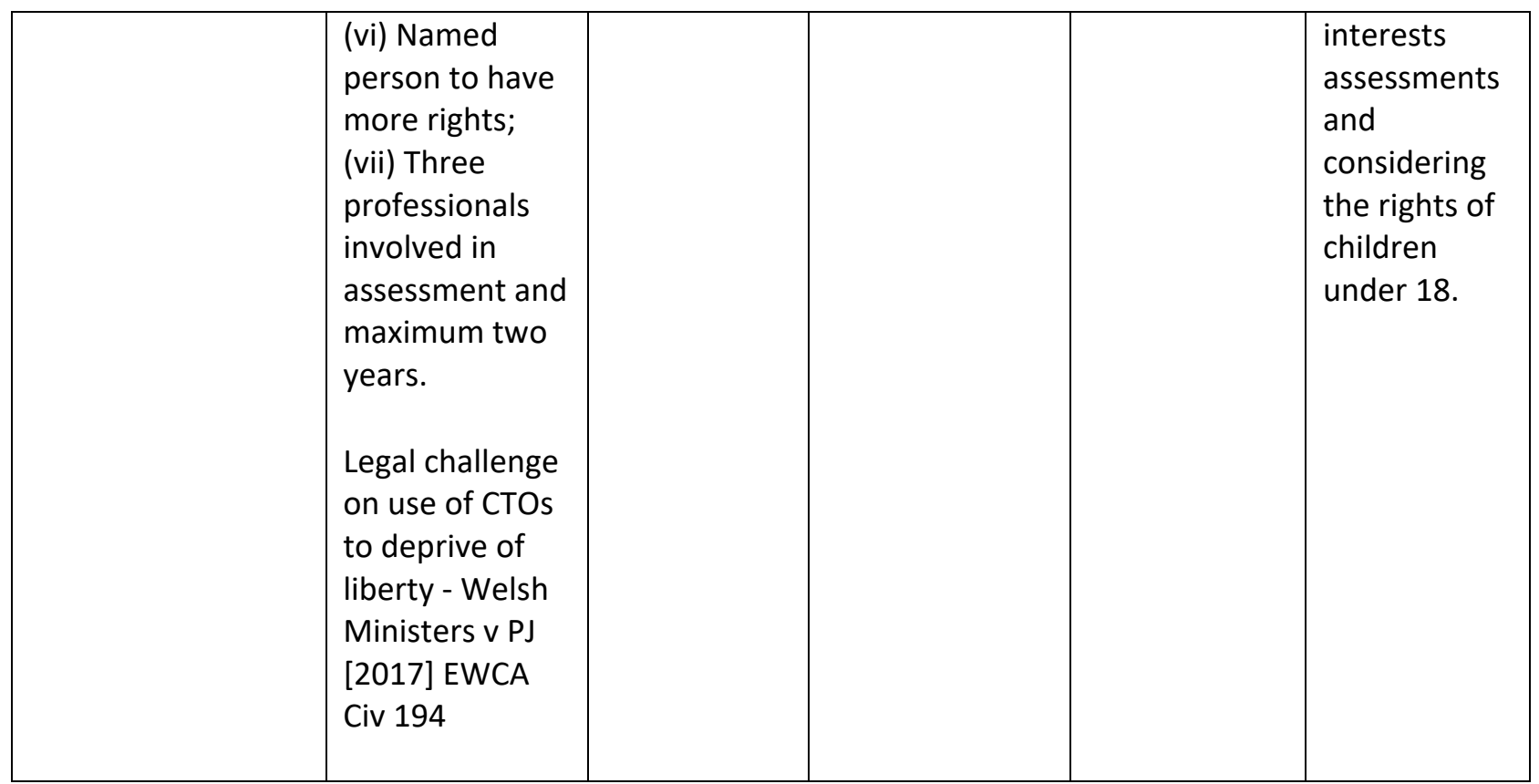

